\title{
Pengaruh Kinerja QoS Untuk Layanan VoIP Berdasarkan Jarak Dari Base Station Pada Jaringan WiMAX
}

\author{
Murhaban $^{1}$, Muhammad Bilal' ${ }^{2}$ Muhammad Nurtanzis Sutoyo ${ }^{1}$ \\ Dosen Teknik Mesin - Universitas Teuku Umar \\ Dosen Teknik Informatika - Universitas Nusantara PGRI Kediri \\ Dosen Sistem Informasi - Universitas Sembilanbelas November Kolaka \\ E-mail :murhabani@gmail.utu,m.bilal@gmail.com,grm_iyes@gmail.com
}

\begin{abstract}
Abstrak
Metode Handover digunakan untuk mempertahankan koneksi tetap terjaga. Hal tersebut berkaitan dengan performansi dikarenakan proses pengalihan kanal trafik secara otomatis pada mobile station untuk berkomunikasi tanpa terjadinya pemutusan hubungan. Faktor utama keberhasilan dalam melakukan handover terletak pada quality of service yang menyediakan tingkat jaminan layanan berbeda-beda dalam mengatur dan memberikan prioritas trafik pada jaringan seperti aplikasi voice over IP (VoIP) atau komunikasi voice memanfaatkan jaringan internet dalam permasalahan berdasarkan jarak base station.

Berdasarkan pengujian yang dilakukan untuk metode hard handover dan metode soft handover berdasarkan jarak base station menggunakan aplikasi voice over internet protocol pada mobile station. Diperoleh hasil dengan nilai jitter $0.015 \mathrm{~ms}-0.21 \mathrm{~ms}$, dan hasil delay $35.5 \mathrm{~ms}-45.8 \mathrm{~ms}$ hal tersebut membuktikan bahwa pengaruh jitter dan delay terhadap handover dengan aplikasi VoIP masih dalam tahapan toleransi yang diizinka. Dan berdasarkan hasil penelitian ini jarak antara satu base station dengan station lainnya sangat berpengaruh untuk mendapatkan kulaitas layanan yang lebih baik. Kata Kunci : Handover, Jitter, Delay, VoIP, Quality of Service
\end{abstract}

\section{PENDAHULUAN}

Teknologi worldwide interoperability for microwave access (WiMAX), merupakan salah satu teknologi akses nirkabel pita lebar (broadband wireless access) yang memiliki kecepatan akses yang tinggi dengan jangkauan yang luas. WiMAX sendiri mengacu pada standar yang dikeluarkan oleh institute of electrical and electronics engineering (IEEE) 802.16, umumnya masing-masing standar tersebut terus dikembangkan dengan varianvarian yang memiliki keunggulan pada penggunaan atau kondisi tertentu. [1]

Teknologi WiMax telah di ujicoba pada beberapa negara, teknologi ini dikenal dengan WiMAX yang dikenal juga dengan nama IEEE 802.16. WiMAX saat ini terbagi menjadi 2 kategori besar, yaitu IEEE 802.16d dan IEEE 802.16e. Keduanya sangat berbeda dimana IEEE 802.16d untuk segmen fixed dan nomadic sedangkan IEEE 802.16e bagi segmen portable dan mobile. [2]

Faktor utama keberhasilan dalam melakukan proses hard handover dan soft handover dengan aplikasi user VoIP terletak pada kualitas jaringan (sinyal). [3] menyatakan tugas dari kualitas jaringan yang baik akan menyediakan tingkat jaminan layanan yang 
berbedabeda untuk mengatur dan memberikan prioritas trafik pada jaringan seperti voice over IP (VoIP) atau komunikasi voice memanfaatkan jaringan internet. Aplikasi tersebut sangat dipengaruhi oleh jitter dan delay. Sehingga tujuan akhir untuk memberikan network service yang lebih baik dan terencana dengan dedicated bandwidth, jitter dan latency yang terkontrol dan meningkatkan loss karakteristik.

Penelitian untuk handover dengan kecepatan user yang berubah-ubah, seperti yang dilakukan oleh [4] untuk layanan file tranfer protocol, VoIP GSM, video conference, dan web browsing untuk hard handover. Pengujian terhadap penelitian tersebut dengan menggunakan simulasi telah dilakukan namun belum ada hasil yang dapat diimplementasikan pada soft handover.

\section{Tahapan Proses Hard Handover pada Mobile WiMAX}

Jaringan mobile memungkinkan user untuk mengakses layanan dalam keadaan bergerak sehingga memberikan "kebebasan" kepada pengguna dalam hal mobilitas. Akan tetapi, kebebasan ini membawa ketidak-pastian bagi sistem mobile. Mobilitas dari pengguna mengakibatkan perbedaan dinamis baik dalam kualitas hubungan maupun level interferensi, kadang terjadi keadaan dimana seorang user harus berganti BS yang melayaninya. Proses ini dikenal sebagai handover (HO). Handover menjamin keberlangsungan layanan nirkabel (wireless) ketika user bergerak menuju batas-batas sel. Hard Handover (HHO) adalah kelompok dari prosedur HO dimana semua hubungan yang lama dilepaskan sebelum hubungan radio yang baru dibentuk. Bagi pembawa (bearer) real-time hal ini berarti pemutusan hubungan yang singkat dari bearer

\section{METODE PENELITIAN}

\subsection{Worldwide Interoperability for Microwave Access}

Worldwide interoperability for microwave access (WiMAX) adalah sebuah sistem komunikasi nirkabel baru yang diharapkan dapat memberikan tingkat komunikasi data rate lebih baik di metropolitan area networks (MAN) [5]. Dalam beberapa tahun terakhir, IEEE 802.16 kelompok kerja telah mengembangkan jumlah standar untuk WiMAX. Standar pertama diterbitkan pada tahun 2001, yang bertujuan untuk mendukung komunikasi pada frekuensi 10-66 GHz. Pada tahun 2003 IEEE 802.16a diperkenalkan untuk memberikan spesifikasi lapisan fisik tambahan untuk pita frekuensi 2-11 GHz. Kedua standar tersebut kemudian direvisi pada 2004 (IEEE 802.16-2004). Baru-baru ini, IEEE802.16e juga telah disetujui sebagai resmi standar untuk aplikasi [6] ditunjukkan pada Gambar 1. 


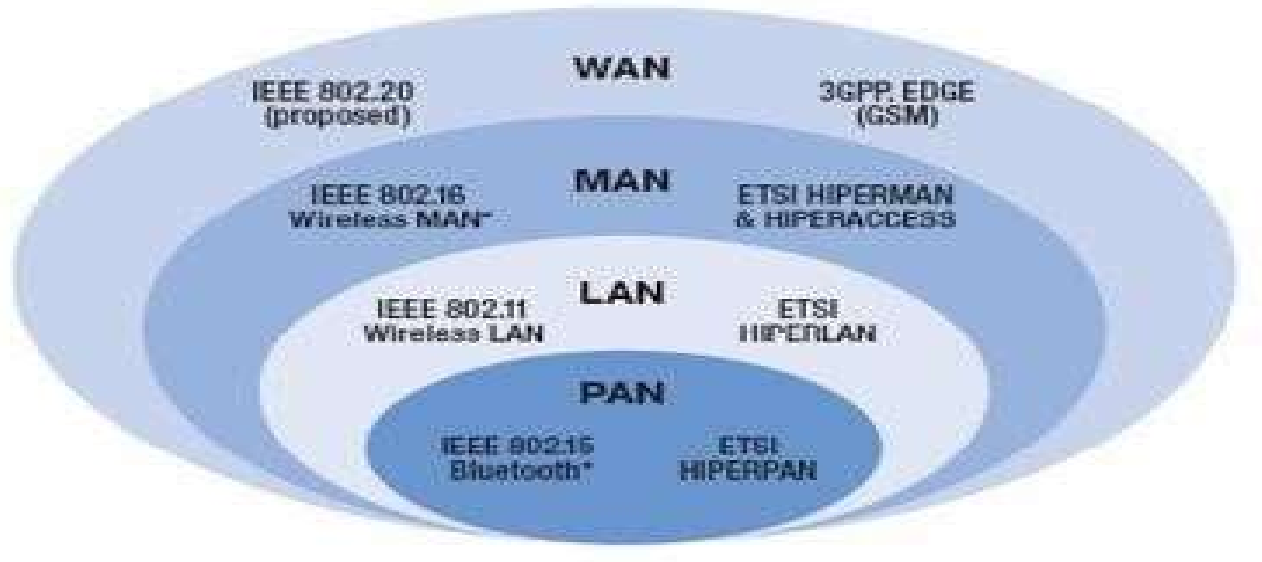

Gambar 1 Standar-standar yang mendukung komunikasi MAN disatukan dengan Standar

\subsection{Arsitektur Sistem} WiMAX [6].

Menurut standar IEEE 802.16e, teknologi mobile WiMAX mendukung dua operasi mode: point to multipoint (PMP) dan mesh untuk mendsitribusikan trafik. Simulasi jaringan WiMax ini dimodelkan dengan sebuah jaringan yang menggunakan topologi mesh yaitu topologi penggabungan antara point to point dan point to multipoint yang digunakan untuk melayani akses langsung ke pelanggan [1] untuk digunakan meng-handle subcriber site (mobile station). Adapun kemampuan dari mobile station untuk bertahan dan berkomunikasi dalam jaringan tergantung dari tipe QoS yang ditawarkan, tetapi dalam simulasi ini digunakan tipe QoS real time polling service didesain mendukung aliran service real-time dengan membangkitkan paket data variable-size. Bentuk topologi yang digunakan adalah arsitektur jaringan mesh sepeti pada Gambar $2 \mathrm{~b}$.

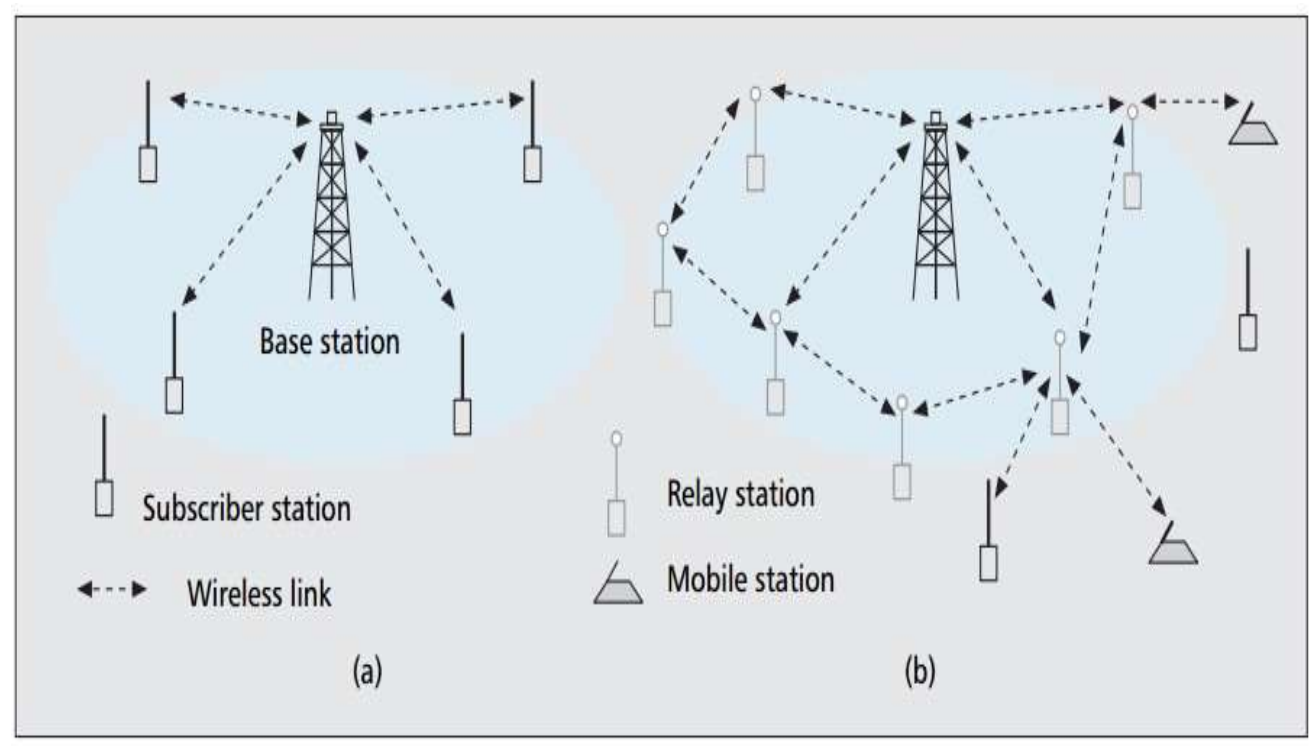

Gambar 2 Arsitektur Jaringan WiMAX; a) topologi PMP; b) Topologi Mesh [6]

Pemodelan Topologi mesh pada jaringan WiMAX dapat lebih praktis karena menerapkan konsep routing dimana semua data ditransmisikan dengan menemukan perkiraan rute 


\section{Jurnal Mekanova}

Vol 4. No. 2, April 2018

ISSN : 2502-0498

terpendek ke node tujuan. Data dikonfigurasikan otomatis mengalir di sepanjang jalur, melompat dari node yang satu ke node yang lain hingga mencapai node tujuan. Setiap perangkat terhubung secara langsung ke perangkat lainnya yang ada di dalam jaringan mulai dari transport site (server) menuju ke base station dan dari base station menuju ke subcriber site (mobile station). Hubungan dedicated links menjamin data dikirimkan ke user tujuan dapat lebih cepat karena semua link digunakan tujuan berkomunikasi dengan user yang dituju saja. Topologi ini juga memiliki sifat robust, yaitu Apabila terjadi gangguan pada koneksi satu BS dan BS lain tidak mempengaruhi koneksinya

\subsection{IP Address Node}

Routing merupakan sebuah pengalamatan menuju alamat tujuan tanpa melalui/bisa melalui host lain. Dimana sebuah base station dengan IP address 172.5.0.71 dengan kelas subnet mask kelas B 255.255.0.0 mengirimkan data atau melayani mobile station dengan alamat IP 192.168.1.1 kelas subnet mask kelas C 255.255.255.0. Pada OPNET Modeler 14.5 akan dikonfigurasikan IP routing parameter dengan mengkonfirusikan IP pada interface information (IF). Sedangkan IP address digunakan sebagai alamat dalam hubungan antar node jaringan WiMAX, sehingga paket data yang dikirim melalui area tranport site harus dipastikan sampai ketujuan akhir yaitu mobile station.

Node dalam jaringan berbasis IP diberikan IP address pada IP host parameter melalui interface information berstatus active dengan kelas subnet mask masing-masing yang digunakan untuk saling berinteraksi satu sama lainnya dan berperan dalam mentransmisikan paket data dari node ke node. Berikut konfigurasi IP address pada nodenode tersebut.

1. Server

Tabel 1 Konfigurasi IP Address Server

\begin{tabular}{|c|c|c|}
\hline Interface Name & Address & Subnet Mask \\
\hline IF0 & 172.9 .0 .71 & 255.255 .0 .0 \\
\hline
\end{tabular}

Berdasarkan Tabel 1 IF0 server berkomunikasi dan terhubung ke IF0 backbone (Tabel 2). Server bagian transport site sebagai sentral dalam jaringan mengirim trafik dan mengontrol memakai subnet mask kelas B. Backbone sebagai penghubung atau yang menjembatani aliran trafik.

2. Backbone

Tabel 2 Konfigurasi IP Address Backbone

\begin{tabular}{|c|c|c|}
\hline Interface Name & Address & Subnet Mask \\
\hline IF0 & 172.0 .0 .72 & 255.255 .0 .0 \\
\hline IF1 & 172.1 .0 .72 & 255.255 .0 .0 \\
\hline IF2 & 172.2 .0 .72 & 255.255 .0 .0 \\
\hline IF3 & 172.3 .0 .72 & 255.255 .0 .0 \\
\hline IF4 & 172.4 .0 .72 & 255.255 .0 .0 \\
\hline IF5 & 172.5 .0 .72 & 255.255 .0 .0 \\
\hline IF6 & 172.6 .0 .72 & 255.255 .0 .0 \\
\hline
\end{tabular}




\begin{tabular}{|l|l|l|}
\hline IF7 & 172.7 .0 .72 & 255.255 .0 .0 \\
\hline IF8 & 172.8 .0 .72 & 255.255 .0 .0 \\
\hline IF9 & 172.9 .0 .72 & 255.255 .0 .0 \\
\hline
\end{tabular}

Tabel 2 IF 0 backbone akan terhubungan dengan IF0 server (Tabel 1), sedangkan IF1IF9 akan terhubung dengan IF4 (Tabel 4.3) dari setiap base station. Tugas dari backbone memastikan paket yang dikirim sampai ke base station dan menjaga dari kejadian fault tolerance dan menjaga agar tidak terjadi transfer bottleneck. Backnone memakai subnet mask kelas B. 3. Base Station

Tabel 3 Konfigurasi IP Address Base Station

\begin{tabular}{|c|c|c|}
\hline \multirow{2}{*}{} & \multicolumn{2}{|c|}{ Interface information } \\
\cline { 2 - 3 } & IF4 & IF8 \\
\hline SBS 0 & 172.0 .0 .71 & 192.168 .1 .1 \\
\hline
\end{tabular}

\begin{tabular}{|c|c|c|}
\hline TBS 1 & 172.1 .0 .71 & 192.168 .2 .1 \\
\hline TBS 2 & 172.2 .0 .71 & 192.168 .3 .1 \\
\hline TBS 3 & 172.3 .0 .71 & 192.168 .4 .1 \\
\hline TBS 4 & 172.4 .0 .71 & 192.168 .5 .1 \\
\hline TBS 5 & 172.5 .0 .71 & 192.168 .6 .1 \\
\hline TBS 6 & 172.6 .0 .71 & 192.168 .7 .1 \\
\hline TBS 7 & 172.7 .0 .71 & 192.168 .8 .1 \\
\hline TBS 8 & 172.8 .0 .71 & 192.168 .9 .1 \\
\hline
\end{tabular}

Berdasarkan Tabel 3 terdapat satu serving BS dan delapan target BS dengan subnet mask kelas B, dimana IF 4 terhubung dengan IF1-IF9 backbone (Tabel 2 ) dan IF8 akan berkomunikasi dengan IF0 (Tabel 4) pada mobile station. Semua perintah pada base station dalam melakukan handover dan pengaturan trafik dikontrol oleh mobile telephone switching office (MTSO) melalui mobile switching center (MSC) terutama ketika melakukan peralihan dengan penentua metode handover berdasarkan kecepatan mobile.

4. Mobile Station

Tabel 4 Konfigurasi IP Address Mobile Station

\begin{tabular}{|c|c|c|}
\hline Interface Name & Address & Subnet Mask \\
\hline IF0 & $192.168 .1 .1-6$ & 255.255 .255 .0 \\
\hline
\end{tabular}

IF0 mobile station pada Tabel 4 memakai subnet mask kelas $\mathrm{C}$ dan akan terhubung dengan semua base station yang dilewati baik SBS maupun TBS melalui IF 8 (Tabel 4.3). Service dari base station akan diberikan ketika mobile melakukan mobilitasnya sekali putaran (one way) yaitu ketika melewati batas ceverage area dari setiap base station. 


\section{Jurnal Mekanova \\ Vol 4. No. 2, April 2018 \\ ISSN : 2502-0498}

\subsection{Rancangan VoIP}

Penelitian ini menggunakan aplikasi voice over internet protocol dengan memanfaatkan jaringan mobile WiMAX untuk melakukan komunikasi suara. Model VoIP yang dirancang mengacu pada ITU-T, [7]) menggunakan standar H.323 untuk komunikasi multimedia realtime dan konferensi melalui jaringan packet-based. Untuk mendukung voice over internet protocol dalam jaringan digunakan protokol TCP/IP untuk memproses dan mengirim data. Pada bagian transport layer akan digunakan protokol TCP untuk menjaga hubungan komunikasi end-to-end dengn konsep mengirim dan menerima segmensegmen informasi yang panjang data bervariasi, serta menjamin reabilitas hubungan komunikasi karena akan melakukan perbaikan terhadap data yang rusak dengan menerima dan mengirim sinyal acknoledment (ack). Dalam Aplikasi VoIP, TCP juga digunakan pada saat signaling, serta untuk menjamin setup suatu call pada sesi signaling.

Model VoIP dirancang dengan jumlah user yaitu 1 user (pertama), 3 user (kedua) dan 6 user (ketiga). Semua user tersebut akan melewati base station dan di mulai dari base station 0 sampai base station 8 , sedangkan lawan bicara tidak bergerak dengan jumlah user sama dan berada di dalam jaringan yang sama. Ketika komunikasi berlangsung waktu diam antara penelepon dan penerima saat melakukan komunikasi memiliki nilai silence minimum 4 second dan maksimum 60 second.

Waktu bicara antara penelepon dan penerima saat melakukan komunikasi atau talk spurt minimum 8 second dan maksimum 1800 second. Hal tersebut memberi keleluasaan dalam berkomunikasi tetapi dalam penelitian ini dibatasi dengan nilai maksimum, dan ketika komunikasi dua arah terjadi maka periode talkspurt dan silence akan bekerja secara bergantian. Prioritas permintaan paket oleh aplikasi dalam simulasi menggunakan protokol signaling SIP type of service interactive voice (6), dengan tugas utama memodifikasi dan mengakhiri sesi multimedia. Paket data dikirim dari transport site (server) dan diterima subcribe site (mobile station).

Adapun tugas utama antara pengirim paket (server) dan penerima paket (VoIP) adalah. a) Pengiriman Paket

Pengirim akan bertanggunag jawab dalam beberapa hal seperti :

1. Mengatur sending rate setelah mendapatkan informasi yang diberikan penerima

2. Mengirim paket

3. Memastikan paket yang dikirim sampai ketujuan dengan cara mendeteksi dan koreksi kesalahan dengan mengirim sinyal acknowledge (ack).

Pengiriman paket akan dikontrol oleh transmission control protocol (TCP). Bit rate yang dikirim menggunakan encoder scheme G.711 dengan besaran laju bit rate 64 kbps yang didistribusikan ke penerima atau user. Bila ada paket yang gagal atau packet loss maka protocol TCP akan mengirim sinyal ack dan jika sinyal ack tidak diterima dalam interval waktu tertentu maka sistem akan memastikan bahwa paket benar-benar gagal, maka paket data akan dikirim kembali. Dalam simulasi menggunakan OPNET 14.5 protocol TCP khususnya duplicate ack threshol harus selalu dalam keadaan enable. b) Penerima Paket Selama komunikasi berlangsung pengirim akan menerima paket ack dari penerima. Paket tersebut mengandung informasi yang dibutuhkan pengirim untuk mengatur sending rate sebagai usaha mencegah congestion. Sending rate akan selalu diperbaharui setiap pengirim menerima paket ack dan jika waktu duplicate ack threshol digunakan. Maka duplicate ack threshol akan memicu retransmisi, dengan jumlah maximum ack segments setelah sinyal ack dikirim 2 kali ke pengirim. 
Jurnal Mekanova

Vol 4. No. 2, April 2018

ISSN : 2502-0498

\subsection{Skenario Pengujia $n$}

Berdasarkan rumusan masalah Sub Bab I, maka skenario pengujian dalam penelitian ini dilakukan pengujian quality of service saat melakukan handover untuk mempetahankan agar koneksi tetap terjaga sehingga pemutusan hubungan tiba-tiba pada mobile station dihindari.

Pengujian dengan variasi skenario pada Tabel 5 dan Tabel 6 disetiap skenario dilakukan tiga kali pengujian dengan jumlah user yang berbeda, dan divariasikan kecepatan serta jarak antar base station. Setiap pengujian user melakukan mobilitas dan melewati delapan base station dengan rute searah serta berlawan arah jarum jam, ketika setiap melewati base station akan melakukan handover dengan kecepatan user konstan, setelah melakukan handover maka akan diambil hasil jitter, delay dan throughput untuk kemudian dianalisa. Dengan laju bit rate yang dikirim ke user menggunakan codec G.711 dengan besaran $64 \mathrm{kbps}$.

Tabel 5 Variasi Skenario Hard Handover

\begin{tabular}{|c|c|c|c|c|c|}
\hline Kecepatan & Jarak Antar & Skenario & \multicolumn{3}{|c|}{ User } \\
\hline 20 & \multirow{3}{*}{$5 \& 9$} & 1 & 1 & 3 & 6 \\
\hline 45 & & 2 & 1 & 3 & 6 \\
\hline 60 & & 3 & 1 & 3 & 6 \\
\hline
\end{tabular}

Tabel 6 Variasi Skenario Soft Handover

\begin{tabular}{|c|c|c|c|c|c|}
\hline $\begin{array}{c}\text { Kecepatan } \\
(\mathrm{Km} / \mathrm{jam})\end{array}$ & $\begin{array}{c}\text { Jarak Antar } \\
\text { BS }(\mathrm{Km})\end{array}$ & Skenario & \multicolumn{4}{|c|}{ User } \\
\hline 65 & \multirow{3}{*}{$5 \& 9$} & 1 & 1 & 3 & 6 \\
\hline \multirow{2nnnyyy}{*}{55} & & 2 & 1 & 3 & 6 \\
\hline 100 & & 3 & 1 & 3 & 6 \\
\hline
\end{tabular}

\section{HASIL DAN PEMBAHASAN}

\subsection{Pengujian Handover Untuk Jarak Base Station}

Pengujian ini akan dilakukan untuk mengetahui kualitas handover berdasarkan jarak antara 1 base station dengan base station yang lainnya. Nilai dari jitter, delay dan throughput, akan dianalisan berdasarkan skenario pengujian pada jaringan WiMAX sampai 


\section{Jurnal Mekanova \\ Vol 4. No. 2, April 2018 \\ ISSN : 2502-0498}

terjadinya handover dengan user (VoIP) bergerak memanfaatkan protocol TCP. Simulasi ini dilakukan dengan OPNET Modeler 14.5 educational.

Hasil pengujian handover dengan jarak antara base station divariasikan jaraknya yaitu 5 $\mathrm{km}$ dan $9 \mathrm{~km}$, dengan keceepatan yang berbeda dan penambahan user aktif. Pengujian akan dilakukan menggunakan metode hard handover dan soft handover dengan rute mobile station melewati 8 base station berlawanan arah jarum jam. Dalam simulasi pengujian ini menggunakan protokol TCP dengan bit rate $64 \mathrm{Kbps}$ per panggilan ketika mobile station.

\subsubsection{Hasil Jitter}

Gambar 3 memperlihatkan ketika handover untuk jarak antar base station $5 \mathrm{~km}$ dengan besaran nilai jitter yaitu 0.015 millidetik (6 user) pada kecepatan $60 \mathrm{~km} / \mathrm{jam}$ (hard handover), hal tersebut dikarenakan proses paket data yang dikirim tidak langsung diesekusi dan terjadi perbedaan interval waktu antara pengiriman dan penerimaan paket data, berbeda dengan soft handover untuk nilai jitter 0.0038 millidetik pada kecepatan 100 $\mathrm{km} / \mathrm{jam}$. Perbedaan tersebut diakibatkan karena collision dan congestion dalam jaringan, Sehingga jarak antara base station akan mempengaruhi kondisi sinyal yang diberikan ketika melakukan handover, dimana ketika memasuki area handoff tersebut quality of service harus benar-benar terjamin. Selanjutnya Gambar 3 memperlihatkan kualitas jitter terbaik ketika melakukan handover dengan jarak base station $5 \mathrm{~km}$ untuk kecepatan 65 $\mathrm{km} / \mathrm{jam}$ dengan 1 user yaitu 0.001 millidetik, kondisi tersebut terjadi karena respon cepat antara BS serving dan BS target ketika mobile station me-request permintaan perlihan service dari BS serving.

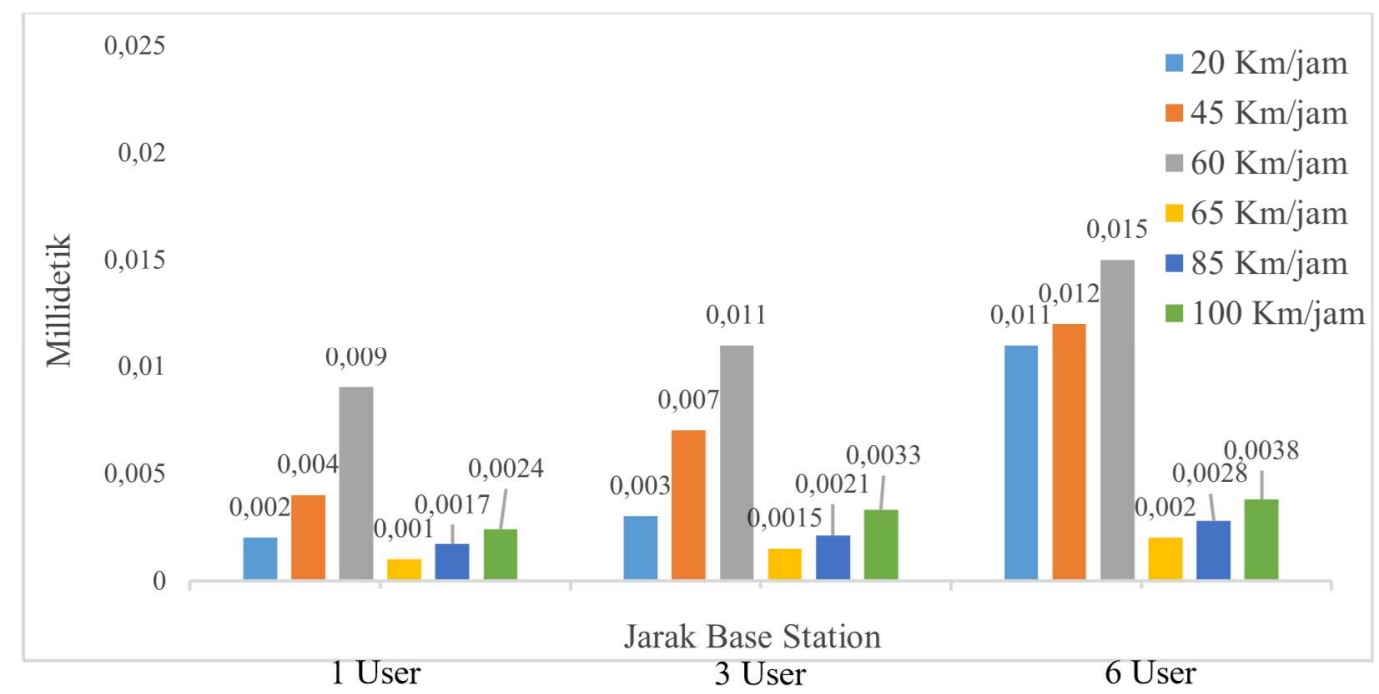

Gambar 3 Jitter Hard Handover dan Soft Handover untuk Jarak Base Station 5 km Selanjutnya pada Gambar 3 memperlihatkan nilai jitter dengan jarak antar base station 9 $\mathrm{km}$ ketika mobile station ketika melakukan handover. Pada jarak base station $9 \mathrm{~km}$ tersebut menghasilkan nilai jitter lebih besar (longgar) untuk kecepatan $60 \mathrm{~km} / \mathrm{jam}$ yaitu 0.021 millidetik (6 user), sedangkan pada kecepatan $65 \mathrm{~km} / \mathrm{jam}$ nilai jitter 0.0014 millidetik (1 user). Hal tersebut membuktikan bahwa semakin jauh area jangkauan base station akan semakin menurun qualitas of service yang diberikan terhadap mobile station. Akan tetapi sebelum melakukan handover mobile station selalu akan menentukan rasio keefektifan 
Jurnal Mekanova

Vol 4. No. 2, April 2018

ISSN : 2502-0498

sinyal antara serving base station dengan target base station. Berikut Gambar 4 memperlihatkan hasil jitter dengan jarak antar base station $9 \mathrm{~km}$.

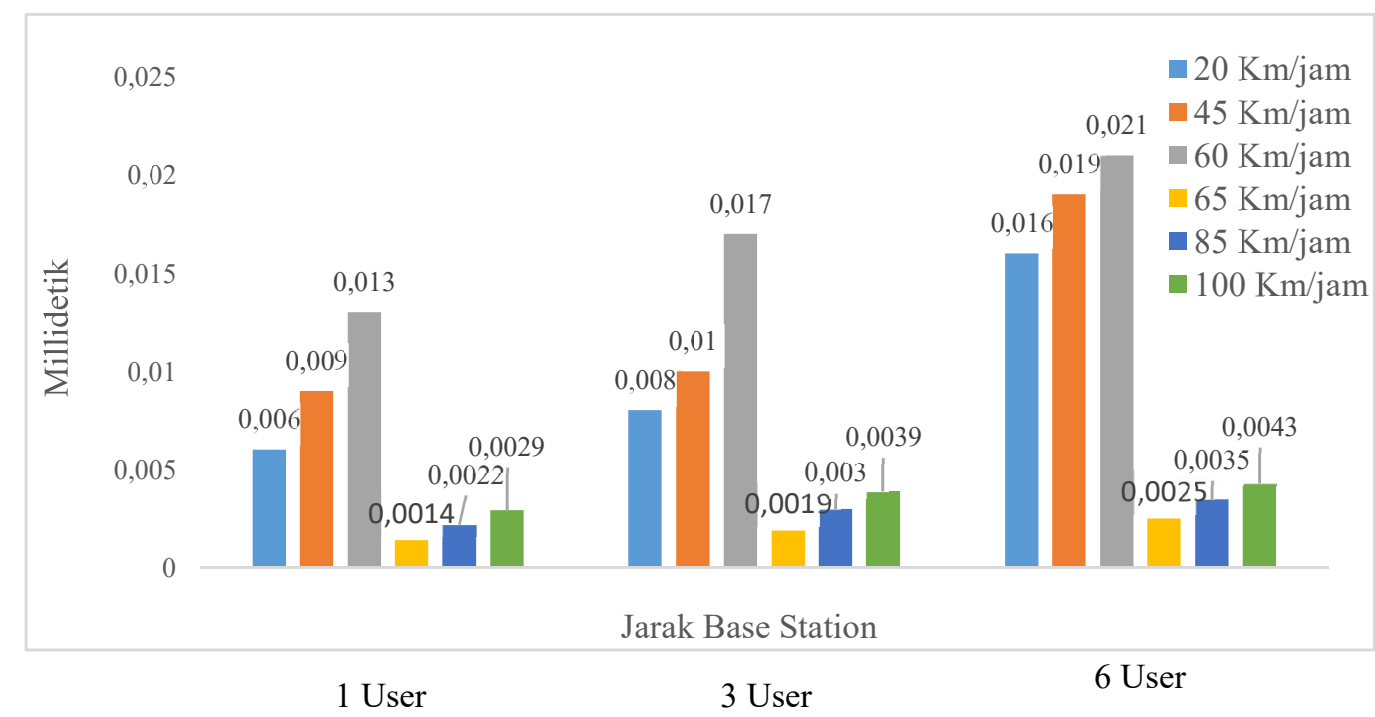

Gambar 6.8 Jitter Hard Handover dan Soft Handover untuk Jarak Base Station 9 km

\subsubsection{Hasil Delay}

Hasil delay pada Gambar 5 yaitu ketika mobile station melakukan handover untuk prioritas sasaran 1 target base station dengan jarak antar BS yaitu $5 \mathrm{~km}$. Terjadi kenaikan delay yang signifikan pada kecepatan $100 \mathrm{~km} / \mathrm{jam}$ yaitu 35.5 millidetik (soft handover) dan delay minimal pada kecepatan $65 \mathrm{~km} / \mathrm{jam}$ yaitu 11.1 millidetik, besarnya delay yang terjadi pada kecepaan $100 \mathrm{~km} / \mathrm{jam}$ dipengaruhi oleh waktu tunggu yang dilayani pada sebuah trunk dan akibat meminimalkan buffer jitter dari sisi penguna untuk proses decoding dan decompresi paket data yang terima berdasarkan rekomendasi (ITU-T, 2003). Hasil delay dengan jarak base station $5 \mathrm{~km}$ seperti pada Gambar 6 .

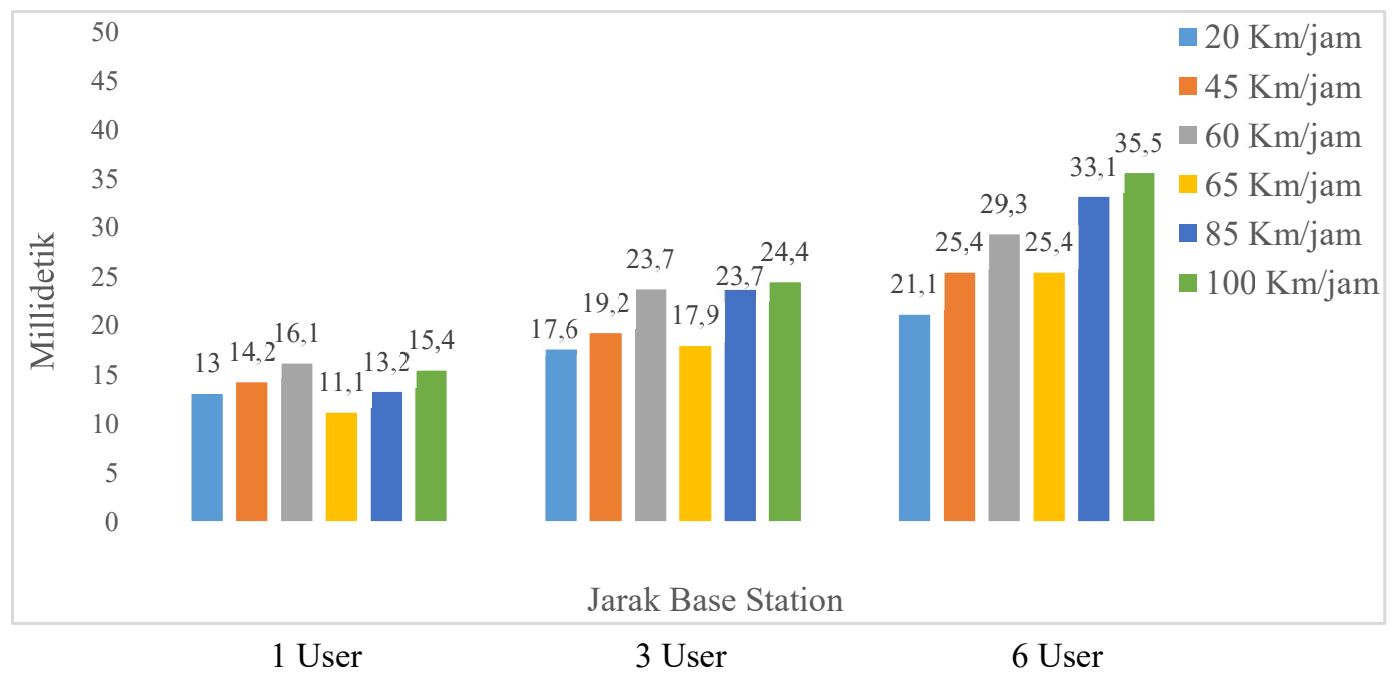

Gambar 6 Delay Hard Handover dan Soft Handover untuk Jarak Base Station 5 km

Sedangkan pada Gambar 7 menunjukkan hasil handover yang jarak base station-nya $9 \mathrm{~km}$, dengan rata-rata nilai delay yang dihasilkan masih dapat diterima berdasarkan standar 
Jurnal Mekanova

Vol 4. No. 2, April 2018

ISSN : 2502-0498

yang dikeluarkan Cisco (2004). Nilai delay tertinggi terjadi pada kecepatan $100 \mathrm{~km} / \mathrm{jam}(6$ user) yaitu 45. 8 millidetik, besaran nilai delay dipengaruhi untuk menekan buffer delay untuk mengatasi naiknya nilai jitter ketika terjadi antrian data yang akan diproses dalam jaringan. Selanjutnya nilai delay terkecil terjadi pada kecepatan $65 \mathrm{~km} / \mathrm{jam}$ (1 user) yaitu 14.5 millidetik dengan jarak antar base station $9 \mathrm{~km}$. Hasil terkecil nilai delay ketika melakukan handover akibat terhindar dari antrian yang lama karena hanya memakai 1 user dan proses paketisasi digital voice sample yang terjadi menjadi cepat. Gambar 7 menunjukkan hasil handover dengan jarak antar base station $9 \mathrm{~km}$.

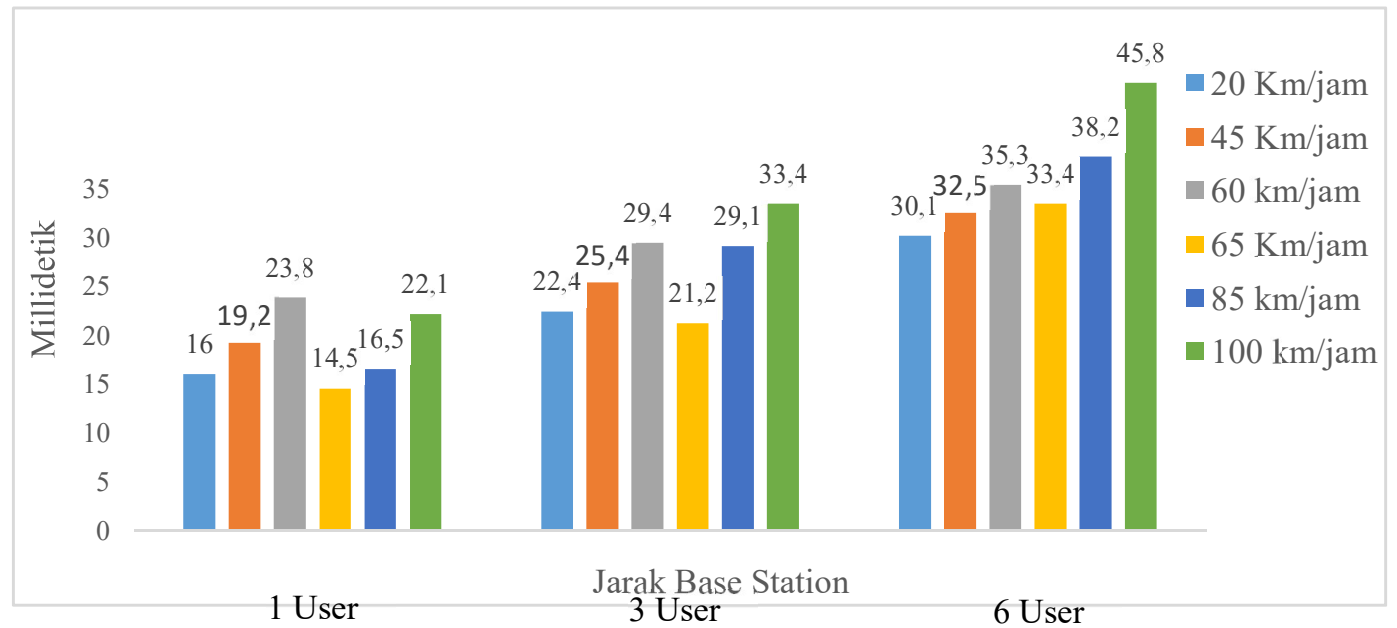

Gambar 7 Delay Hard Handover dan Soft Handover untuk Jarak Base Station 9 km

$$
\begin{aligned}
& 50 \\
& 45 \\
& 40
\end{aligned}
$$

\section{KESIMPULAN}

Berdasarkan hasil penelitian terhadap jaringan WiMAX menggunakan metode handover khususnya metode hard handover dan soft handover, dengan layanan pada mobile station voice over internet protocol dan disimulasikan memakai optmized network engineering tools, dapat disimpulkan : 


\section{Jurnal Mekanova \\ Vol 4. No. 2, April 2018 \\ ISSN : 2502-0498}

1. Pengujian tiga skenario metode hard handover dan soft handover, dilakukan menggunakan tiga kali pengujian dimana pada nilai jitterr terjadi perbedaan interval waktu antara pengiriman paket dan penerimaan paket, dengan besaran trafik yang dikirim $64 \mathrm{Kbps}$ (low bandwidth) congestion dalam jarigan dapat dihindari. Nilai ratarata jitter $0.015 \mathrm{~ms}$ ms metode hard handover dan $0.21 \mathrm{~ms}$ metode soft handover, hasil tersebut tidak menunjukkan perbedaan signifikan terhadap penggujian dua metode handover yang menggunakan aplikasi voice over internet protocol, sehingga mekanisme handover untuk layanan VoIP bekerja efektif dan ideal pada jarigan WiMAX akan tetapi jitter yang dihasilkan lebih baik dengan jarak base station $5 \mathrm{Km}$.

2. Pengujian handover menggunakan metode hard handover dan soft handover dengan aplikasi pada user voice over internet protocol. Terjadi kenaikan delay yang signifikan ketika penambahan beban user aktif dilakukan, hal tersebut terjadi pada saat coding atau penggabungan data, compression, decompression, hingga data diurai atau decoding. Nilai rata-rata untuk masing-masing 35.5 ms metode hard handover dan $38.8 \mathrm{~ms}$ soft handover, kenaikan tertinggi delay terjadi setiap pengujian ketiga dengan 6 user aktif pada jarak base station $9 \mathrm{Km}$. Hasil ini menunjukkan bahwa Aplikasi voice over internet protocol sangat sensitif terhadap delay akan tetapi delay dalam pengujian ini masih dalam batasan toleransi yang diizikan

\section{V.SARAN}

Adapun saran yang dapat disampaikan untuk penelitian berikutnya:

1. Penelitian selanjutnya sebaiknya dilakukan secara real (nyata), dengan variasi frekuensi band yang berbeda serta fokus bagaimana meminimalkan delay.

2. Perlu penelitian lebih lanjut terhadap dengan menggunakan standar coding dan kompresi dengan memvariasikan method compression yang memakai bandwidth yang berbeda.

\section{DAFTAR PUSTAKA}

[1] Wibisono, G., Hantoro, G. D., 2006, WiMAX Teknologi Broadband Wireless Access (BWA) Kini dan Masa Depan., Informatika Bandung.

[2] Bachtiar. Y., Santoso. I., Zahra. A.A., 2013, Evaluasi Kinerja Tahapan Handover Pada Pengguna Unggal Layanan Ftp Jaringan Mobile Wimax (IEEE 802.16E).

[3] Gunawan, H., Herlinawati., Komarudin, M., Muhamad., 2012, Simulasi dan Analisis Kualitas Layanan pada Jaringan Mobile WiMAX. Electrician Jurnal Rekayasa dan Teknologi Elektro., Volume: 6 No.3. Hal., 185-181.

[4] Setianto,W., Uke, K. U., Mufti, N. A., 2008, Analisis Vertical Handoff pada Interworking antara Jaringan Akses Wireless 802.11e dan 802.16, Teknik Telekomunikasi Institut Teknologi Telkom., Bandung.

[5] Vaughan, S. J., Nichols., 2004, Achieving Wireless Broadband with WiMAX, IEEE Comp, vol. 37, issue 6, June 2004., pp. 10-13.

[6] Kejie, L., Qian, Y., Chen, H. H., 2007, A Secure and Service-Oriented Network Control Framework for WiMAX Networks. IEEE Communications Magazine., May 2007., pp. 124-130.

[7] ITU-T., 2003, Transmission Systems and Media, Digital Systems and Networks 
Jurnal Mekanova

Vol 4. No. 2, April 2018

ISSN : 2502-0498

"One-Way Transmission Time" Recommendation G.114, International Telecommunication Union. 